\title{
Numerical Simulation for Optimization of ZnTe-Based Thin-Film Heterojunction Solar Cells with Different Metal Chalcogenide Buffer Layers Replacements: SCAPS-1D Simulation Program
}

\author{
Samer H. Zyoud ${ }^{1,2,4}$, Ahed H. Zyoud ${ }^{3}$, Atef Abdelkader ${ }^{1,2}$, Naser M. Ahmed ${ }^{4}$
}

\begin{abstract}
In this study, Zinc Telluride (ZnTe)-based solar cells, which are metallic dichalcogenide materials, are used as a solar cell absorbent with the formation appropriate for solar cell use. The data has been analyzed by SCAPS-1D structures software. The replacement of Cadmium Sulfide CdS (buffer) layer by other green and save suitable materials has been investigated. The substituted buffer layers have been $\mathrm{ZnSe}, \mathrm{ZnS}, \mathrm{CdSe}$, and $\mathrm{In}_{2} \mathrm{~S}_{3}$. The higher device performance efficiency parameters have been found out when using CdS and ZnSe as buffer layers. SCAPS-1D shows that the optimal p-n junction device eff]iciency parameters have been achieved when the ZnTe (absorber) layer thickness is between 1200-1500 nm, while the ZnSe (buffer) layer thickness is between 20-60 nm, and the thickness of ZnO:Al (window) layer is $25 \mathrm{~nm}$. The results of the simulation provide important hints that may enhance the performance of the cell with empirical studies useful in practical implementation. Copyright (C) 2021 The Authors.

Published by Praise Worthy Prize S.r.l. This article is open access published under the CC BY-NC-ND license (http://creativecommons.org/licenses/by-nc-nd/3.0/).
\end{abstract}

Keywords: Heterojunction, ZnTe, ZnSe, Solar Cell, SCAPS-1D

\begin{tabular}{|c|c|c|c|}
\hline \multirow{4}{*}{ AM1.5G } & \multirow[t]{2}{*}{ Nomenclature } & \multirow{2}{*}{$\begin{array}{l}P_{\text {in }} \\
P(x)\end{array}$} & \multirow{2}{*}{$\begin{array}{l}\text { Input power } \\
\text { Hole concentration }\end{array}$} \\
\hline & & & \\
\hline & Standard terrestrial solar spectrum & $q$ & Elementary charge \\
\hline & "Air Mass 1.5" & $Q E \%$ & Quantum efficiency percentage \\
\hline Al & Aluminum & $\mathrm{QE}(\lambda)$ & Quantum efficiency in terms of \\
\hline CB & Conduction band & & wavelength \\
\hline$C d S$ & Cadmium Sulfide & $R$ & Recombination rate \\
\hline$D_{n}$ & Electron diffusion constant & SCAPS-1D & Solar Cell Capacitance Simulator in 1 \\
\hline$D_{n}$ & Hole diffusion constant & & Dimension \\
\hline$e$ & Elementary electrical charge & $T$ & Temperature \\
\hline $\mathrm{EC}$ & Conduction band edge & $T(\lambda)$ & Optical transmission \\
\hline EF & Fermi energy level & VB & Valence Band \\
\hline EV & Valence band edge & $V_{O C}$ & Open-circuit voltage \\
\hline $\mathrm{FF}$ & Fill Factor & $\mathrm{ZnO}$ & Zinc Oxide \\
\hline G & Generation rate & $\mathrm{ZnS}$ & Zinc Sulfide \\
\hline$G(x)$ & Generation profile & $\mathrm{ZnSe}$ & Zinc Selenide \\
\hline$h$ & Blank constant & $\mathrm{ZnTe}$ & Zinc Telluride \\
\hline$h v$ & Photon energy & $\lambda$ & Wavelength \\
\hline$I(\lambda)$ & Photogenerated current & $\psi$ & Electrostatic potential \\
\hline $\mathrm{In}_{2} \mathrm{~S}_{3}$ & Indium sulfide & $\varphi$ & Potential difference \\
\hline$J_{O}$ & Saturation current density & $\eta \%$ & Conversion efficiency \\
\hline$J_{n}$ & Electron current densities & $\varepsilon_{o}$ & Vacuum permittivity \\
\hline$J_{p}$ & Hole current densities & $\varepsilon_{r}$ & Relative permittivity \\
\hline$J_{S C}$ & Short-circuit current density & $\rho_{P}$ & Holes distribution \\
\hline $\mathrm{J}-\mathrm{V}$ & Current-voltage & $\rho_{n}$ & Electrons distribution \\
\hline $\mathrm{k}$ & Boltzmann constant & $\mu_{n}$ & Electron mobility \\
\hline$k T / q$ & Thermal voltage & $\mu_{p}$ & Hole mobility \\
\hline$n$ & Carrier concentration & $\emptyset_{i}$ & Spectral power density \\
\hline NA & Charged impurities of acceptor & $v_{\mathrm{i}}$ & Frequency \\
\hline $\begin{array}{l}\text { ND } \\
n(x)\end{array}$ & Charged impurities of donor & $\Delta \lambda_{\mathrm{i}}$ & Interval between the two neighboring \\
\hline & Electron concentration & & values of wavelength \\
\hline
\end{tabular}


$\varphi_{p}(\lambda)$

\section{Photon flow}

\section{Introduction}

Environmentally friendly and renewable sources of energy are important goals [1]-[3]. The conversion of solar light to electricity is also one of the imperative prospects [4]-[11]. Solar cell photovoltaic devices have emerged as a well-run and relatively sustainable energy conversion technology, which is environmentally friendly and commercially non-expensive in larger-scale production.

In the current situation, the economic and high conversion efficiency photovoltaic devices are designed for the generation of electricity. Semiconductor devices play a significant role in such applications and they can be extensively used in photovoltaic power generation. Photovoltaic cells absorb the radiation of sunlight and convert it into electricity [12]. Polycrystalline and monocrystalline photovoltaic cells are made from elemental and combined materials. Monocrystalline materials exhibit higher conversion efficiencies compared with polycrystalline materials. Their production cost is higher than the polycrystalline materials. A polycrystalline material in photovoltaic research and applications has gained more attention due to satisfactory performance, low-cost manufacturing, reliability, and stability [13]. Thin-film semiconductor solar cell technology is one of the most promising green energy sources. It has advantages like being a clean energy source, an inexpensive technology (prepared from available, non-expensive materials), easily prepared (it can be prepared by simple techniques such as electrodeposition, chemical bath deposition, solution growth, and thermal evaporation) [7]. A small amount of raw materials is sufficient to prepare a large surface area of nano-thin-film.

Additionally, it demands little maintenance, it has a long life, and it is recyclable. Toxic and environmentally hazardous materials have been investigated in thin-film solar cell research. Such materials are cadmium, arsenic, beryllium, lead, mercury, and others [14]-[19]. Reducing these materials' impact on the environment is one of the main targets of research and development. Replacing such hazardous with other safe and fewer hazardous materials can help achieving the target issue, in addition to the use of a minimum amount of such materials with no significant reduction in solar cell device performance efficiency. Thin-film photovoltaic solar cells belong to second and third-generation solar cell technology. These types of solar cells are manufactured by depositing one or more layers of semiconducting materials on a metal, plastic, or glass substrate. Commercially thin-film photovoltaic solar cells are used in various technologies, such as Copper Indium Gallium Selenide (CIGS) [20], cadmium telluride (CdTe) [21], kesterite and perovskite solar cell technologies [22]. Thin-film photovoltaic technologies are based on various types of light absorbers semiconductor materials with different thicknesses that vary from few $\mathrm{nm}$ to few $\mu \mathrm{m}$. This makes these types of devices flexible and lightweight. The absorption coefficient of a thin film of polycrystalline solar cell devices is higher than monocrystalline materials.

Therefore, a very thin layer of the absorber layer is sufficient for the effective absorption of sunlight [23].

For a better understanding of the device characteristics, numerical modeling or analysis is a computer simulation program that can play a significant role by modeling different device structures that can save time and cost for the research community. It is a tool to study system behavior having complex mathematical models and it helps providing analytical solutions. For the numerical modeling of solar cells, the physical parameters of the material are taken as input for the simulation software. In order to translate the practical or real device, it is mandatory to take experimental data of $\mathrm{J}-\mathrm{V}$ characteristics and functional parameters such as power conversion efficiency, fill factor, open-circuit voltage, and short circuit current in device modeling. Furthermore, ZnTe is cubic structured, it is a p-type semiconductor with a $2.25 \mathrm{eV}$ energy gap and it has promising applications for various electronic optical uses such as heterojunction solar cells. ZnTe can be formed with n-type CdS thin layer or another buffer such as $\mathrm{CdSe}, \mathrm{ZnS}, \mathrm{ZnSe}$, and $\mathrm{In}_{2} \mathrm{~S}_{3}$, a p-n junction that is more useful for photovoltaic solar devices. These devices can absorb a wide range of solar spectrum in the conversion process [24].

Skhouni, O. et al. (2016) have reported the modeling of $\mathrm{ZnTe}$ based solar cell and a numerical study of the effect of $\mathrm{ZnTe}$ absorber thickness on the different output parameters of the proposed $\mathrm{ZnO} / \mathrm{CdS} / \mathrm{ZnTe}$ solar cell device [25]. The results show that all the main characteristics of the modeled solar cell have increased with increasing $\mathrm{ZnTe}$ thickness up to $2 \mu \mathrm{m}$ and at this optimum thickness, conversion efficiency $\eta$, open-circuit voltage $V_{O C}$, short circuit current density $J_{S C}$ and fill factor $\mathrm{FF}$ are $10 \%, 1.81 \mathrm{~V}, 7 \mathrm{~mA} / \mathrm{cm}^{2}$ and $78.84 \%$ respectively. The importance of using $\mathrm{ZnTe}$ in solar cells is due to its high performance, stability, low production cost, and high absorptivity. All these properties make it suitable for the substitution of silicon solar cells [26][29]. The buffer layer usually has a focal role in heterojunction thin-film solar cells.

The reach-in photons to the absorption layer are passing through the buffer layer. Accordingly, the photons lost due to absorption in the buffer layer should be minimized. Therefore, electrical resistance and low surface recombination in the buffer layer are required. Providing thin-film solar cell stability is essential in presenting the buffer layer in-between the absorber layer and the transparent windows layer.

Accordingly, the buffer layer should have a highenergy gap. Such behavior allows most of the visible radiation to pass through to the absorption layer. On the other hand, the bandgap edges of the buffer and the absorption layer should be approximately compatible in 
order to allow the depletion layer to overlap. Metal chalcogenides are suitable for the role of a buffer layer in heterojunction thin-film solar cells. Such metal chalcogenides are $\mathrm{CdS}, \mathrm{CdSe}, \mathrm{ZnS}, \mathrm{ZnSe}$, and $\mathrm{In}_{2} \mathrm{~S}_{3}$. Among the metal chalcogenide, $\mathrm{CdS}, \mathrm{CdSe}$, and CdTe have commonly used compounds in heterojunctions thinfilm solar cells. Such compounds have an environmentally hazardous impact. Green and environmentally friendly (less hazardous) compounds (e.g. $\mathrm{ZnS}, \mathrm{ZnSe}, \mathrm{ZnO}, \mathrm{Zn}_{1-\mathrm{x}} \mathrm{Mg}_{\mathrm{x}} \mathrm{O}$, and $\mathrm{In}_{2} \mathrm{~S}_{3}$ ) should be investigated and evaluated as a replacement to the conventional hazardous semiconductors used in heterojunction thin-film solar cells [30]-[32].

Numerical simulations can be utilized to explore the possible effects of different materials on the final solar cell characteristics.

Findings of such numerical studies and analysis can be used in order to improve the performances of the device [2], [33]-[38].

In this work, green and environmentally friendly semiconductors (e.g. $\mathrm{ZnS}, \mathrm{ZnSe}$, and $\mathrm{In}_{2} \mathrm{~S}_{3}$ ) have been investigated and compared with $\mathrm{CdS}$ and $\mathrm{CdSe}$ as a buffer layer in heterojunction thin-film solar cell. The SCAPS-1D will be used here to evaluate numerically the photovoltaic devices performance efficiency.

The device performance efficiency will be evaluated by calculating the efficiency parameters (open circuit potential $V_{O C}$, short circuit current density $J_{S C}$, fill factor percentage $\mathrm{FF} \%$, and efficiency percentage $\eta \%$ ). The optimum thickness of the ZnTe (absorber) layer (the selected buffer layer), and the $\mathrm{ZnO}: \mathrm{Al}$ (window) layer thickness will be investigated in addition to assessing the quantum efficiency. The band diagram will be investigated as well.

The rest of the paper is organized as follows.

Section II explains the numerical modeling and the materials input parameters. This section will describe the methodology of the device simulation and modeling, the input parameters, and the used mathematical equations. Section III represents the results and the discussion details with subtitles such as effect of buffer layers on the $\mathrm{J}-\mathrm{V}$ characteristics, optimization of the $\mathrm{ZnTe}$ (absorber) layer thickness, modeling and optimization of $\mathrm{ZnSe}$ (Buffer) layer thickness, and modeling and optimization of $\mathrm{ZnO}: \mathrm{Al}$ (window) layer thickness. Finally, the conclusion is presented in the final section of this paper.

\section{Numerical Modeling and the Materials Input Parameters}

The heterojunction solar cell devices layers general are constructed by a glass substrate sheet.

A conducting molybdenum layer is deposited on the glass substrate sheet, followed by the absorption layer, which is usually a thick layer that absorbs enough amounts of photons to excite electrons to the conduction band.

Next, the suitable buffer layer is deposited on the absorption layer and a transparent conductive window layer is deposited over the buffer layer. Finally, the heterojunction is protected by a layer (glass) that is posed as a front layer.

The suggested device is constructed from a ZnTe as an absorption layer deposited on a molybdenum layer that is deposited on the glass sheet substrate.

A buffer layer of different suggested semiconducting materials $\left(\mathrm{CdS}, \mathrm{CdSe}, \mathrm{ZnS}, \mathrm{ZnSe}\right.$, and $\left.\mathrm{In}_{2} \mathrm{~S}_{3}\right)$ is deposited on the absorption layer.

A window layer of $\mathrm{Al}$-doped $\mathrm{ZnO}$ in the ration of $3 \%$ is deposited on the buffer layer. Finally, the front glass sheet is deposited. The schematic diagram of the suggested $\mathrm{Mo} / \mathrm{ZnTe} / \mathrm{Buffer}$ layer/ZnO:Al is shown in Fig. 1.

The SCAPS-1D software is used here for solar cell efficiency numerical simulation calculation. It has been developed for polycrystalline thin-film devices-based solar cell and it has many parameters of the electrical one, which can be studied or simulated including $\mathrm{V}_{O C}$, $J_{S C}, \mathrm{FF} \%, \eta \%, \mathrm{QE} \%$ [39]-[42].

All these calculations are suitable for dark and light conditions, with a change in illuminations, temperatures, and the thin film structure (which can consist of many layers up to seven layers).

The material properties for each layer of the suggested device should be uploaded to the SCAPS-1D software program.

The starting condition (bias voltage, working temperature, illumination, etc.) should be set, as shown in Table I. the properties of reflection and transmission of the front (right) and back (left) contacts are shown in Table II. SCAPS-1D can solve Poisson and continuity equations for electrons and holes Equations (1) and (2) [42], [43]:

$$
\frac{d^{2} \Psi}{d x^{2}}=\frac{e}{\varepsilon_{o} \varepsilon_{r}}\left[P(x)-n(x)+N_{D}-N_{A}+\rho_{P}-\rho_{n}\right]
$$

where $\Psi$ is the electrostatic potential, $e$ is the elementary electrical charge, $\varepsilon_{r}, \varepsilon_{o}$ are the relative and the vacuum permittivity, $p$ and $n$ are the hole and the electron concentrations, $N_{D}, N_{A}$ are the charged impurities of donor and acceptor, $\rho_{p}$ and $\rho_{n}$ are the holes and the electrons distribution, respectively:

$$
\frac{d J_{n}}{d x}=\frac{d J_{p}}{d x}=G-R
$$

where $J_{n}$ and $J_{p}$ are the electron and the hole current densities, $R$ is the recombination rate, and $G$ is the generation rate.

Carrier transport occurs by drift and diffusion according to Equations (3) and (4), respectively:

$$
\begin{aligned}
& J_{n}=D_{n} \frac{d n}{d x}+\mu_{n} n \frac{d \varphi}{d x} \\
& J_{p}=D_{p} \frac{d p}{d x}+\mu_{p} p \frac{d \varphi}{d x}
\end{aligned}
$$


TABLE I

Electrical And Other Properties Of The Thin-Film Solar Cell Device Layers Used In The Simulation

\begin{tabular}{|c|c|c|c|c|c|c|c|}
\hline Parameter & $\mathrm{p}-\mathrm{ZnTe}$ & n- CdS & n-CdSe & $\mathrm{n}-\mathrm{ZnS}$ & $\mathrm{n}-\mathrm{ZnSe}$ & $\mathrm{n}-\mathrm{In}_{2} \mathrm{~S}_{3}$ & $\mathrm{ZnO}: \mathrm{Al}$ \\
\hline Thickness $(\mu \mathrm{m})$ & 1.5 & 0.025 & 0.025 & 0.025 & 0.025 & 0.025 & 0.015 \\
\hline Band gap (eV) & 2.26 & 2.4 & 1.74 & 3.5 & 2.9 & 2.8 & 3.3 \\
\hline Electron affinity $(\mathrm{eV})$ & 3.5 & 4.5 & 4.95 & 4.5 & 4.09 & 4.7 & 4.35 \\
\hline Dielectric permittivity (relative) & 9.67 & 10 & 6.1 & 10 & 10 & 13.5 & 9 \\
\hline $\mathrm{CB}$ effective density of states $\left(\mathrm{cm}^{-3}\right)$ & $7 \times 10^{16}$ & $1.5 \times 10^{18}$ & $1.75 \times 10^{18}$ & $1.5 \times 10^{18}$ & $1.5 \times 10^{18}$ & $1.8 \times 10^{19}$ & $2.2 \times 10^{18}$ \\
\hline VB effective density of states $\left(\mathrm{cm}^{-3}\right)$ & $2 \times 10^{19}$ & $1.8 \times 10^{18}$ & $2.1 \times 10^{19}$ & $1.8 \times 10^{18}$ & $1.8 \times 10^{18}$ & $4 \times 10^{13}$ & $1.8 \times 10^{19}$ \\
\hline Electron thermal velocity $(\mathrm{cm} / \mathrm{s})$ & $1 \times 10^{7}$ & $1 \times 10^{7}$ & $1 \times 10^{7}$ & $1 \times 10^{7}$ & $1 \times 10^{7}$ & $1 \times 10^{7}$ & $1 \times 10^{7}$ \\
\hline Hole thermal velocity $(\mathrm{cm} / \mathrm{s})$ & $1 \times 10^{7}$ & $1 \times 10^{7}$ & $1 \times 10^{7}$ & $1 \times 10^{7}$ & $1 \times 10^{7}$ & $1 \times 10^{7}$ & $1 \times 10^{7}$ \\
\hline Electron mobility $\left(\mathrm{cm}^{2} / \mathrm{Vs}\right)$ & 330 & 50 & 650 & 50 & 50 & 400 & 100 \\
\hline Hole mobility $\left(\mathrm{cm}^{2} / \mathrm{Vs}\right)$ & 80 & 20 & 100 & 20 & 20 & 210 & 25 \\
\hline Shallow uniform donor density ND $\left(\mathrm{cm}^{-3}\right)$ & 0 & $1 \times 10^{22}$ & $1 \times 10^{22}$ & $1 \times 10^{22}$ & $1 \times 10^{22}$ & $1 \times 10^{22}$ & $1 \times 10^{22}$ \\
\hline Shallow uniform acceptor density NA $\left(\mathrm{cm}^{-3}\right)$ & $2 \times 10^{15}$ & 0 & 0 & 0 & 0 & 0 & 0 \\
\hline
\end{tabular}

TABLE II

BACK AND FRONT CONTACT PARAMETERs PROPERTIES

\begin{tabular}{|c|c|c|c|}
\hline & & Left Contact(Back) & Right Contact(Front) \\
\hline \multirow{3}{*}{$\begin{array}{l}\text { Thermionic emission surface recombination } \\
\text { velocity }(\mathrm{cm} / \mathrm{s})\end{array}$} & Electron & $1 \times 10^{7}$ & $1 \times 10^{7}$ \\
\hline & Holes & $1 \times 10^{7}$ & $1 \times 10^{7}$ \\
\hline & Metal work function (eV) & 5 & 4.1 \\
\hline \multirow{2}{*}{ Majority carrier barrier height (eV) } & Relative to EF & 0.4 & 0.1 \\
\hline & Relative to EV or EC & -0.068 & 0.0571 \\
\hline
\end{tabular}

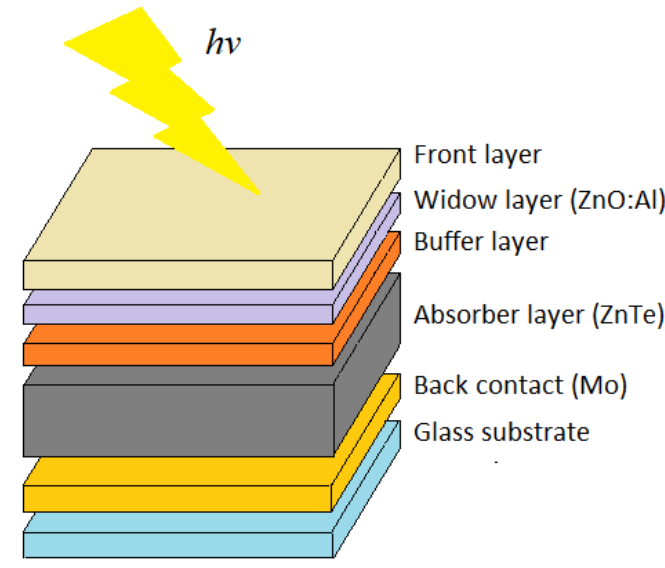

Fig. 1. Schematic arrangement of a thin film- based solar cell layers

The short current density $\left(J_{S C}\right)$ can be found by Equation (5) [44]:

$$
J_{S C}=q \sum T(\lambda) \frac{\emptyset_{i}\left(\lambda_{i}\right)}{h v_{i}} \eta\left(\lambda_{i}\right) \Delta \lambda_{i}
$$

where $q$ is the elementary charge, $T(\lambda)$ is the optical transmission, $\emptyset_{i}$ is the spectral power density, and $\Delta \lambda_{i}$ is the interval between the two neighboring values of wavelength. The open-circuit voltage $\left(V_{O C}\right)$ can be expressed by Equation (6) [45]:

$$
V_{O C}=\frac{n k T}{q} \ln \left(\frac{J_{S C}}{J_{O}}+1\right)
$$

The fill factor percent $(F F \%)$, finds out the maximum power of a solar cell and it can be expressed by Equation (7) [46]:

$$
F F \%=\frac{V_{O C}-\ln \left(V_{O C}+0.72\right)}{V_{O C}+1}
$$

The energy conversion efficiency percent $(\eta \%)$ of thin film can be expressed by Equation (8) [45]:

$$
\eta \%=\frac{V_{O C} \times J_{S C} \times F F \%}{P_{\text {in }}}
$$

The incident light (photons) illumination is $\mathrm{AM} 1.5 \mathrm{G}$ spectra through the calculation of the $\mathrm{J}-\mathrm{V}$ characteristics in this numerical simulation analysis [46]. The input power, $P_{i n}$, from the sun is considered as $1000 \mathrm{~W} / \mathrm{m}^{2}$, and its properties are summarized in Table III.

\section{Results and Discussion}

\section{III.1. Effect of Buffer Layers on the J-V Characteristics}

Fig. 2 shows the $\mathrm{J}-\mathrm{V}$ profiles for the different simulated buffer layers. CdTe and $\operatorname{In}_{2} \mathrm{~S}_{3}$ buffer layers have showed very poor J-V profiles. This behavior discourages using such semiconducting compounds as a buffer layer in ZnTe heterojunction thin-film solar cells.

Table IV represents the solar cell efficiency parameters for the different used buffer layers. CdS, ZnS, and $\mathrm{ZnSe}$ have showed higher efficiency parameters (the difference is very low and not significant). Fig. 3 shows the $\mathrm{QE} \%$ profiles for the studied buffer layers. The profiles have showed no significant difference in the wavelength range of 300-530 nm. An insignificant difference has been shown at a wavelength of less than $300 \mathrm{~nm}$. ZnSe, CdS, and $\mathrm{ZnS}$ show a higher efficiency in the wavelength higher than $530 \mathrm{~nm}$.

TABLE III

THE INCIDENT ILLUMINATION (PHOTONS) SOURCE PARAMETERS

\begin{tabular}{cc}
\hline \hline Spectrum & AM 1-5G1 sun. Spectrum \\
\hline Wavelength range $(\mathrm{nm})$ & $200-4000$ \\
Transmission $\%$ & 100 \\
Ideal light current $G(x)\left(\mathrm{mA} / \mathrm{cm}^{2}\right)$ & 20 \\
Transmission of attenuation filter $\%$ & 100 \\
Ideal light current cell $\left(\mathrm{mA} / \mathrm{cm}^{2}\right)$ & 0 \\
\hline \hline
\end{tabular}


Voltage, $\mathrm{V}$

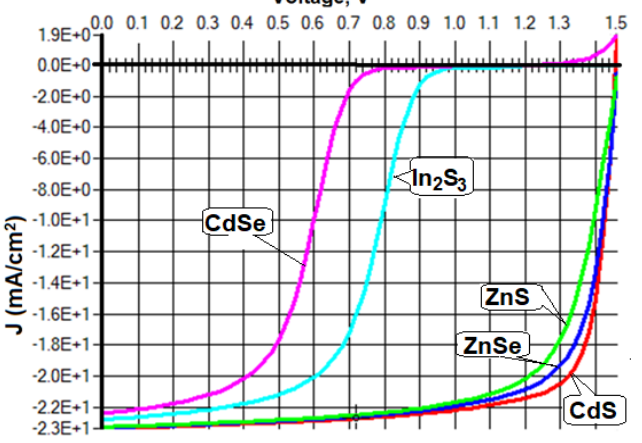

Fig. 2. J-V current curves for the cell. ZnTe layer (acceptor) with different buffer layers. $T=300 \mathrm{~K}$

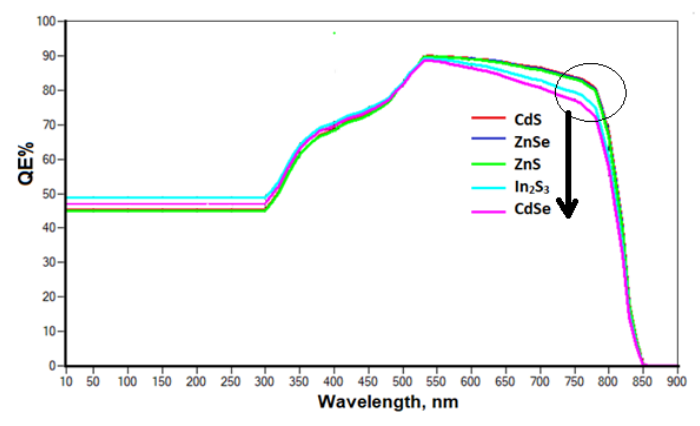

Fig. 3. QE\% spectral profiles of solar cell with different used buffer layers

The results have confirmed that $\mathrm{ZnSe}$ and $\mathrm{ZnS}$ based buffer layers show the highest and the best conversion efficiency of $25.34 \%$ and $24.20 \%$, respectively.

Additionally, CdSe and $\mathrm{In}_{2} \mathrm{~S}_{3}$ based buffer layers have achieved less efficiency of $8.83 \%$ and $12.32 \%$, respectively. Hence, the hazardous properties of $\mathrm{CdS}$ have limited its uses in such devices, while $\mathrm{ZnSe}$ and $\mathrm{ZnS}$ are highly promising candidates as buffer layers in ZnTe heterojunction thin-film solar devices. The spectral response has been evaluated based on the quantum efficiency measurements. QE is defined according to the following Equation (9):

$$
\begin{gathered}
Q E(\lambda)=\frac{\text { Number } \text { of collected electrons }}{\text { Number of incident photons }}= \\
=\frac{I(\lambda) / q}{\varphi_{p}(\lambda)}
\end{gathered}
$$

where $q$ is the elementary electrical charge, $I(\lambda)$ is the photogenerated current, and $\varphi_{p}(\lambda)$ is the photon flow. Fig. 3 represents the quantum efficiency $Q E(\%)$ for different buffer layers on the light spectrum.

TABLE IV

THE SOLAR CELl EFFICIENCY PARAMETERS For DifFERENT BUFFER

\begin{tabular}{ccccc}
\multicolumn{5}{c}{ LAYERS. $T=300 \mathrm{~K}, \mathrm{ZNTE}($ ACCEPTOR) LAYER } \\
\hline \hline Buffer Layer & $V_{O C}(\mathrm{~V})$ & $J_{S C}\left(\mathrm{~mA} / \mathrm{cm}^{2}\right)$ & $\mathrm{FF} \%$ & $\eta(\%)$ \\
\hline $\mathrm{CdS}$ & 1.45 & 23.37 & 78.18 & 26.60 \\
$\mathrm{ZnSe}$ & 1.46 & 23.30 & 74.40 & 25.34 \\
$\mathrm{ZnS}$ & 1.47 & 23.36 & 70.99 & 24.20 \\
$\mathrm{In}_{2} \mathrm{~S}_{3}$ & 0.90 & 22.79 & 36.07 & 12.37 \\
$\mathrm{CdSe}$ & 0.69 & 22.40 & 37.54 & 8.83 \\
\hline \hline
\end{tabular}

\section{III.2. Optimization of the ZnTe (Absorber) Layer Thickness}

The goal of this section is to get a thinner ZnTe layer without affecting the cell performance. The thickness of the $\mathrm{ZnTe}$ (absorber) layer has been numerically marked in the ranges of 600 to $4000 \mathrm{~nm}$, and the parameters of the other materials have been kept constant. The thickness of the ZnSe (buffer) layer is $40 \mathrm{~nm}$, and the thickness of the $\mathrm{ZnO}: \mathrm{Al}$ (window) layer is $60 \mathrm{~nm}$. As a result, the manufacturing cell cost reduction can be achieved by reducing the amount of manufacturing material used. Table $\mathrm{V}$ represents the solar cell efficiency parameters of different chosen thickness. The variation performance of the thin-film at different thicknesses of the $\mathrm{ZnTe}$ (absorber) layer has been calculated using the SCAPS-1D simulator. The best photovoltaic parameters are acquired between $1200-1500 \mathrm{~nm}$ thicknesses of the $\mathrm{ZnTe}$ (absorber) layer. $V_{O C}$ and $J_{S C}$ results show no significant increase with the increase in ZnTe thickness.

However, there is a significant increase in the cell $\mathrm{FF} \%$ and $\eta \%$ with the increase in $\mathrm{ZnTe}$ absorber layer thickness as shown in Figs. 4(a) and (b). The increase in the solar cell $\mathrm{FF} \%$ and $\eta \%$ with $\mathrm{ZnTe}$ layer thickness has achieved the steady-state values at 1200-1500 nm, Figs. 4(c) and (d).

The absorber thickness remains one of the major challenges in ZnTe large-scale solar cells industry and mass production. $\mathrm{FF} \%$ has showed a slight decrease with ZnTe layer thickness higher than $2000 \mathrm{~nm}$. This reduction is attributed to the reduction of bulk resistance of ZnTe material, Fig. 4(c).

The $1200 \mathrm{~nm}$ ZnTe thickness shows an acceptable conversion efficiency of $24.47 \%$ (with $V_{O C}=1.46 \mathrm{~V}, J_{S C}=$ $22.58 \mathrm{~mA} / \mathrm{cm}^{2}$, and $\mathrm{FF} \%=74.16 \%$ ). Simulation results indicate that the optimum thickness of $\mathrm{ZnTe}$ absorption layer will be in the range of 1200-1500 nm. The fabrication of the cell with the thickness of the absorber layer higher than $1500 \mathrm{~nm}$ is unreasonable due to the consumption of more materials without any significant impact on the cell's performance and efficiency.

Although these results are very important to fabricate thin-film solar cell, other parameters can influence the performance of cell and they need to be investigated. The effect of ZnTe thickness on quantum efficiency (QE\%) is presented in Fig. 5.

TABLE V

SOLAR CELl EFFICIENCY PARAMETERS FOR DIFFERENT ZNTE (ABSORBER) LAYER THICKNESS. ZNSE AND ZNO:AL; LAYERS THICKNESS WERE $40 \mathrm{~nm}$ AND $60 \mathrm{~nm}$ RESPECTIVELY AND $T=300 \mathrm{~K}$

\begin{tabular}{ccccc}
\hline \hline Thickness ZnTe, $\mathrm{nm}$ & $V_{O C}(\mathrm{~V})$ & $J_{S C}\left(\mathrm{~mA} / \mathrm{cm}^{2}\right)$ & $\mathrm{FF} \%$ & $\eta \%$ \\
\hline 600 & 1.42 & 21.50 & 63.85 & 19.50 \\
800 & 1.44 & 22.22 & 68.74 & 21.98 \\
1000 & 1.45 & 22.42 & 72.24 & 23.51 \\
1200 & 1.46 & 22.58 & 74.16 & 24.47 \\
1400 & 1.47 & 22.79 & 74.82 & 25.06 \\
1500 & 1.47 & 22.88 & 74.93 & 25.26 \\
1600 & 1.48 & 22.96 & 74.96 & 25.43 \\
2000 & 1.49 & 23.17 & 74.63 & 25.63 \\
3000 & 1.51 & 23.33 & 73.32 & 26.01 \\
4000 & 1.52 & 23.37 & 74.93 & 26.05 \\
\hline \hline
\end{tabular}




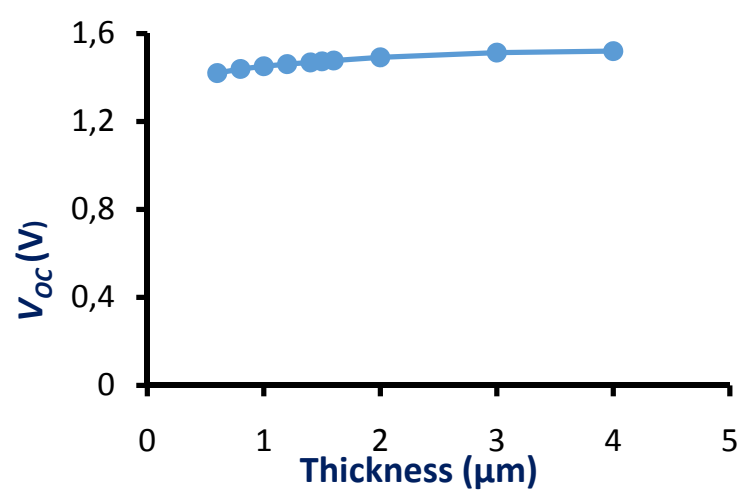

(a)

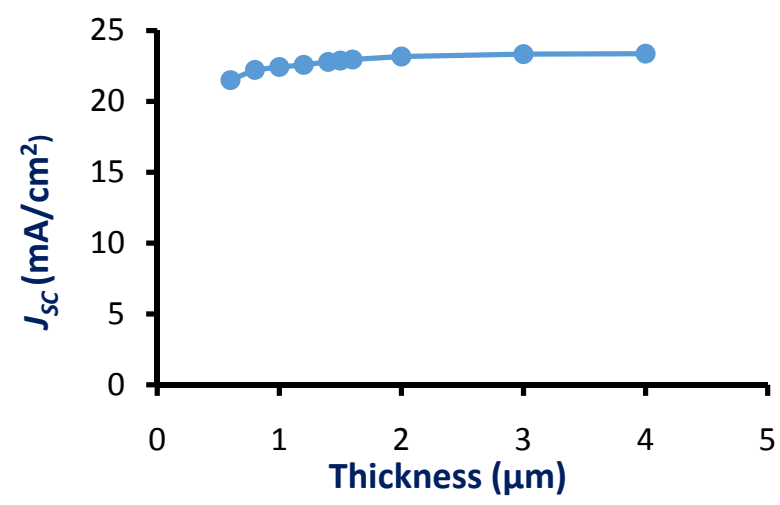

(b)

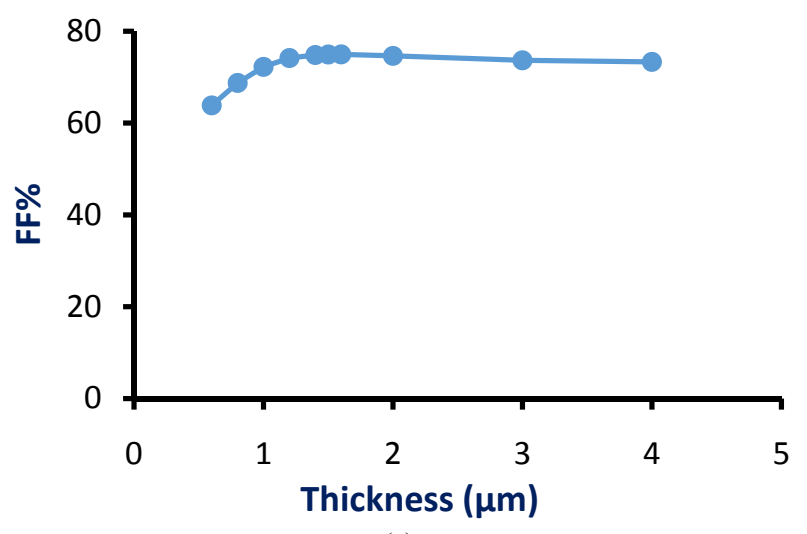

(c)

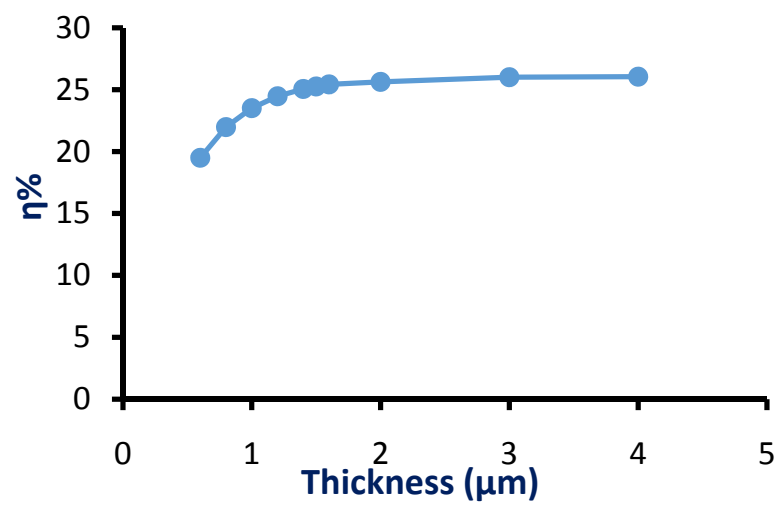

(d)

Figs. 4. The (a) $V_{O C}$; (b) $J_{S C}$;(c) $F F \%$; (d) $\eta \%$, efficiency profiles with different $\mathrm{ZnTe}$ (absorber) layer thickness. $\mathrm{ZnSe}$ and $\mathrm{ZnO}: \mathrm{Al}$; layers thickness are $40 \mathrm{~nm}$ and $60 \mathrm{~nm}$ respectively, $T=300 \mathrm{~K}$

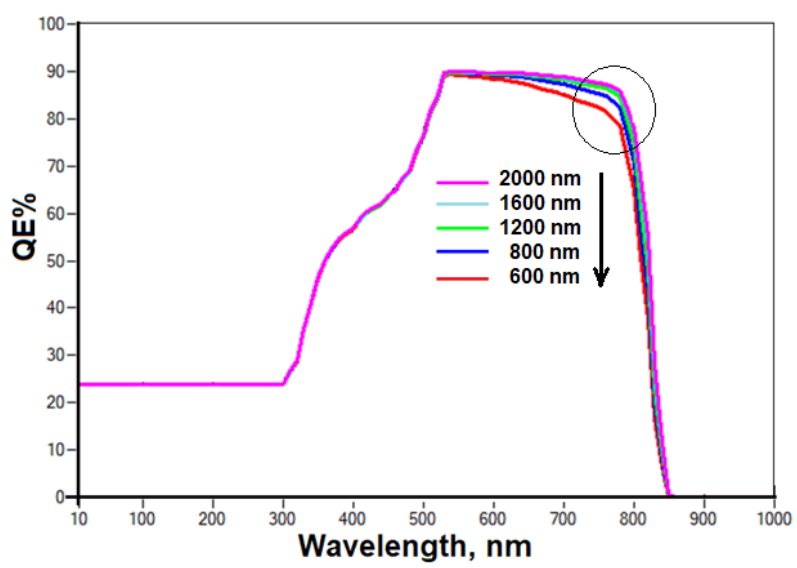

Fig. 5. QE\% spectral profiles of solar cell with different $\mathrm{ZnTe}$ layers thickness

$\mathrm{QE} \%$ has been calculated for different selected ZnTe thicknesses $(600,800,1200,1600$, and $2000 \mathrm{~nm})$. QE\% has been increased by increasing the ZnTe layer thickness. Increasing the thickness of the absorber layer leads to an increase in solar cell quantum efficiency.

However, the rate of increasing quantum efficiency has been slowly affected by the layer thickness higher than $1200 \mathrm{~nm}$. This means that the thickness of $1200 \mathrm{~nm}$ is enough to absorb most of the incident photons. The effect of the ZnTe absorber layer on the quantum efficiency occurs in the region extended from $\lambda=300$ $800 \mathrm{~nm}$ as shown in Fig. 5.

The generation region in thinner absorber cell is near the high recombination back contact region. This will reduce the number of the generated electron-hole pairs and the quantum efficiency. On the other hand, in a thicker absorber cell, the generation process occurs far from the back contact region, which in turn, increases the quantum efficiency. The increase in $\mathrm{QE} \%$ with increasing the absorption layer thickness has been applicable to a specific thickness limit. Understanding the relation between the cell performance and the absorber (ZnTe) layer thickness requires studying the solar cell energy band diagram. The energy band diagram alignment is one of the most important parameters affecting the current heterojunction transmission and the performance of solar cells. Fig. 6 shows that the band diagram is in a good alignment; and the recombination regions are shown. When the absorber layer is thin, the back contact is near the depletion region. This leads to a noticeable increase in the recombination of the back contact. Thus, at the back contact, a large number of photogenerated carriers are recombined and the rest can contribute to quantum efficiency. Therefore, the back contact recombination current decreases as the absorption layer thickness increases, resulting in an increase in solar cell performance. Increasing the absorber layer thickness can improve cell performance, but it cannot be increased excessively, as shown in Figs. 4. This is evident in the case of the absorber layer thickness being more than $2000 \mathrm{~nm}$. $V_{O C}, J_{S C}, \mathrm{FF} \%$, and $\eta \%$ will only increase slightly and reach the steady-state. 
This can be attributed to the fact that photons with a higher wavelength $(>550 \mathrm{~nm}$ ) are absorbed in the bulk absorption layer away from the depletion region. The QE\% profiles for selected ZnTe thickness (600, 800, 1200, 1600, and $2000 \mathrm{~nm}$ ) are shown in Fig. 5. The profiles have showed an increase in the number of absorbed photons with a wavelength longer than $550 \mathrm{~nm}$ up to a limit. The QE\% profiles of 1600 and $2000 \mathrm{~nm}$ are fit together. The increase in the absorber layer thickness can increase the possibility of Quasi-neutral recombination, Fig. 6. The recombination's process falls in three positions: the photo-generated carriers recombine before reaching the depletion region (Region 2 ), the space charge (Region 3), and the absorber/buffer interface (Region 4). It cannot be denied that increasing the thickness of the absorber layer causes the photon to absorb particularly at the high wavelength, but the resulting carriers cannot be used to enhance the performance of the cell and recombination before reaching the depletion region.

\section{III.3. Modeling and Optimization of ZnSe (Buffer) Layer Thickness}

The Mo/ZnTe/ZnSe/Al:ZnO heterojunction solar cell is investigated here in order to achieve a high cell performance and efficiency. The absorber ZnTe and the buffer ZnSe layers should have their conduction bands aligned [47]. ZnSe with (2.7 eV bandgap) has been found out to be a suitable buffer layer for ZnTe (with $2.3 \mathrm{eV}$ bandgap) absorber layer. They have good band alignment to each other [48]. One of the aims of this section is to reduce optical and electrical losses caused by the interface between the absorber and the buffer layers.

$\mathrm{ZnSe}$ is a remarkable material due to its prospect applications in several optical and electronic devices, as a buffer/window material for heterojunction thin-film solar cells. Various methods have been employed for the deposition of $\mathrm{ZnSe}$ thin films. ZnSe can be prepared by simple and inexpensive techniques like electrodeposition, chemical bath deposition, solution growth, and thermal evaporation. Fig. 7 shows the J-V profiles of different ZnSe (buffer) layers thickness. The simulation calculation of $\mathrm{ZnSe}$ layers thickness has been in the range of 10-200 $\mathrm{nm}$. The $\mathrm{ZnTe}$ (absorption) and $\mathrm{Al}: \mathrm{ZnO}$ (window) layers thicknesses have been chosen to be 1500 and $60 \mathrm{~nm}$ respectively, and the operating temperature has been $300 \mathrm{~K}$.

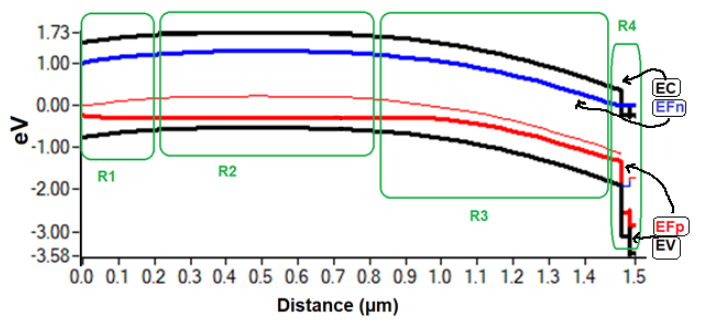

Fig. 6. The cells band diagram: (R1) Back contact recombination, (R2) Quasi-Neutral recombination, (R3) space charge region recombination, (R4) Buffer/Absorber interface recombination

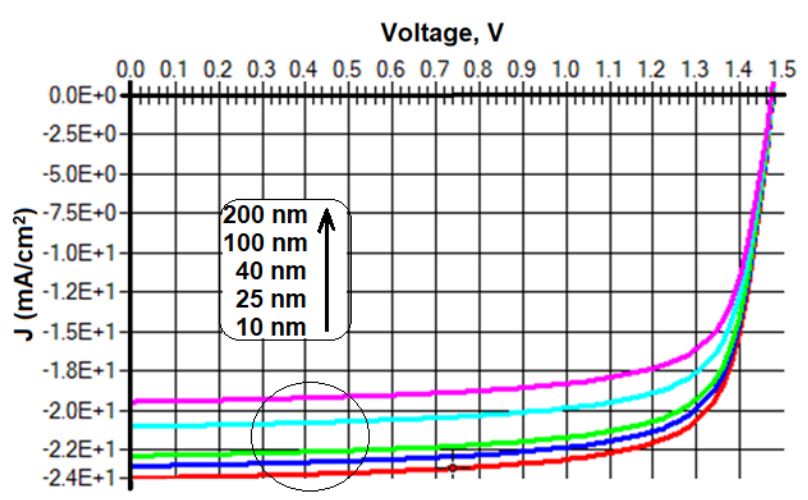

Fig. 7. J-V current curves for the cell. ZnSe buffer layer with different thickness, $T=300 \mathrm{~K}$

Table VI reveals that the cell efficiency parameters have been high in the case of thin buffer layers. This means that the cell parameters performances are lowered in case of increasing the ZnSe (buffer) layer thicknesses.

The $J_{S C}$ and $\eta \%$ values have been affected by the $\mathrm{ZnSe}$ thickness more than $\mathrm{FF} \%$ and $V_{O C}$ values. This lower effect in $V_{O C}$ and $\mathrm{FF} \%$ is attributed to the valance band curtain at the interfaces that appear as spikes and the photon loss that occurs in a thicker $\mathrm{ZnSe}$ layer. As the thickness of the $\mathrm{ZnSe}$ layer increases, the number of absorbed incident photons in the buffer layer will increase. Thus, the number of photons that can pass through the buffer layer to the absorbed by the $\mathrm{ZnTe}$ (absorber) layer will be reduced. The QE\% profiles have showed a decrease in the number of absorbed photons in the wavelength range shorter than $550 \mathrm{~nm}$, Fig. 8. This will lead to a reduction in the production of the electronhole pairs.

A severe decrease has been observed in the $J_{S C}$ and $\eta \%$ in the thicker $\mathrm{ZnSe}$ layers. On the other hand, the thinner $\mathrm{ZnSe}$ layer shows higher performance and an increase in cell efficiency parameters. A thin $\mathrm{ZnSe}$ layer will lead to a reduction in the depletion layer thickness. The depletion layer appears to compensate for the effect of misfit dislocation due to the lattice mismatch between the $\mathrm{ZnSe}$ and $\mathrm{ZnTe}$ layer, Fig. 6. The thinner buffer layer may be resulting in current leakage and the thicker one could lead to a low carrier separation rate. Due to manufacturing techniques and tool limitations, it is not possible to reach a buffer layer thickness of less than 25 nm [49]. Thus, the suggestion is to keep the optimum buffer layer thickness in the range $25-50 \mathrm{~nm}$.

TABLE VI

IMPACT OF ZNSE (BUFFER) LAYER THICKNESS ON THIN FILM PARAMETERS. ZNTE AND ZNO:AL; LAYERS THICKNESS ARE $1500 \mathrm{~nm}$ AND $60 \mathrm{~nm}$ RESPECTIVELY, $T=300 \mathrm{~K}$

\begin{tabular}{ccccc}
\hline \hline Thickness ZnSe, $\mathrm{nm}$ & $V_{O C}(\mathrm{~V})$ & $J_{S C}\left(\mathrm{~mA} / \mathrm{cm}^{2}\right)$ & $\mathrm{FF} \%$ & $\eta(\%)$ \\
\hline 10 & 1.47 & 24.29 & 75.35 & 26.68 \\
20 & 1.47 & 23.77 & 75.20 & 26.35 \\
25 & 1.47 & 23.53 & 75.13 & 26.06 \\
30 & 1.47 & 23.30 & 75.06 & 25.78 \\
40 & 1.47 & 22.88 & 74.93 & 25.26 \\
60 & 1.47 & 22.14 & 74.70 & 24.37 \\
100 & 1.47 & 21.02 & 74.32 & 23.01 \\
200 & 1.47 & 19.45 & 73.74 & 21.12 \\
\hline \hline
\end{tabular}


The impact of the buffer ( $\mathrm{ZnSe}$ ) layer thickness on quantum efficiency $(\mathrm{QE} \%)$ has been calculated; the results are shown in Fig. 8. The figure reveals that $\mathrm{QE} \%$ is decreased by increasing the $\mathrm{ZnSe}$ layer thickness. The variation in $\mathrm{ZnSe}$ thickness and $\mathrm{QE} \%$ is minimal in thicker layers while the variation is observable in thinner layers. The range $25 \mathrm{~nm}$ to $40 \mathrm{~nm}$ has been chosen here as an optimal buffer layer thickness for manufacturing proposes because it is difficult to prepare a very thin layer lower than $\sim 25 \mathrm{~nm}$.

\section{III.4. Modeling and Optimization of $\mathrm{ZnO}: \mathrm{Al}$ (Window) Layer Thickness}

$\mathrm{ZnO}: \mathrm{Al}$ window layer is used to provide optical and electrical access. $\mathrm{ZnO}: \mathrm{Al}$ as a window conducting oxide transparency layer can penetrate the incident radiation and, based on its conductivity, it can collect the charge carriers. $\mathrm{ZnO}$ contains all the required features for the window layer, including the bandgap of $\sim 3.3 \mathrm{eV}$. This bandgap gives the $\mathrm{ZnO}$ an advantage in releasing the photons of wavelengths higher than $385 \mathrm{~nm}$ (Visible and IR radiations) to pass completely through and reach the absorption layer [50]. The simulation calculations have been performed on $\mathrm{ZnO}$ :Al layer thickness range (5 - 200 $\mathrm{nm})$ as shown in Table VII. The ZnTe and ZnSe layer thicknesses have been chosen to be 1500 and $25 \mathrm{~nm}$, respectively, and the operating temperature has been 300 $\mathrm{K}$. The simulation results show that there is no significant decrease in the cell efficiency parameters $\left(V_{O C}, J_{S C}, F F \%\right.$, and $\eta \%$.) with increasing the $\mathrm{ZnO}: \mathrm{Al}$ layer thickness. Using a very thin layer of $\mathrm{ZnO}: \mathrm{Al}$ may result in current leakage and a too thick one could lead to low carrier separation rate. In conclusion, the optimized and preferred layer is selected to be $50 \mathrm{~nm}$ for preparation and manufacturing purposes. The impact of the thickness window ( $\mathrm{ZnO}: \mathrm{Al})$ layer on the $\mathrm{QE} \%$ has been calculated. The QE\% profiles are shown in Fig. 9.

The figure shows that there is no observable effect of the $\mathrm{ZnO}: \mathrm{Al}$ layer thickness on the $\mathrm{QE} \%$ in the wavelength ranged $>300 \mathrm{~nm}$. The $\mathrm{QE} \%$ values have decreased with the increase in $\mathrm{ZnO}$ :Al layer thickness in the wavelength $<300 \mathrm{~nm}$. This reduction will not affect the cell efficiency parameters because solar light radiation lacks such a range of radiations.

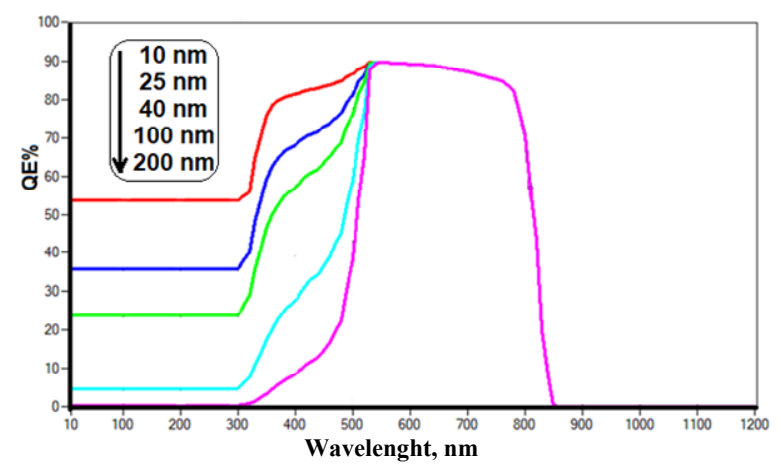

Fig. 8. Spectral response of thin film with different thickness of $\mathrm{ZnSe}$ as buffer layer, $T=300 \mathrm{~K}$

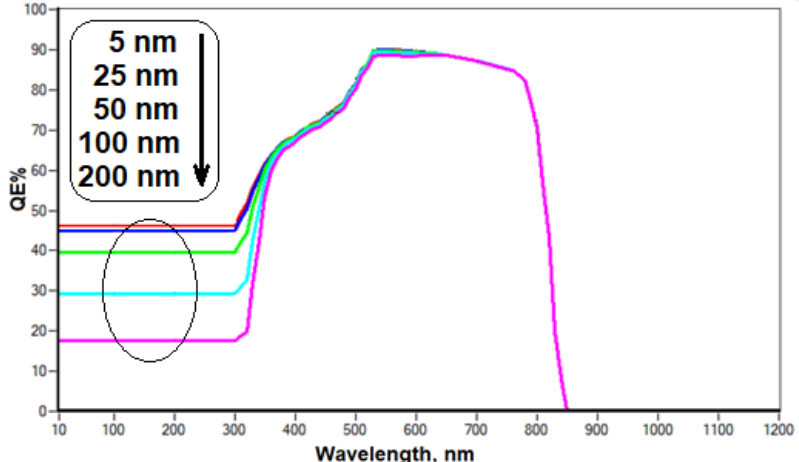

Fig. 9. Spectral response of thin film with different thickness of $\mathrm{ZnO}: \mathrm{Al}$ as window layer. $T=300 \mathrm{~K}$

TABLE VII

THE EFFECT Of ZNO:AL (WINDOW) LAYER THICKNESS ON CELL EFFICIENCY PARAMETERS. ZNTE AND ZNSE LAYERS THICKNESS ARE $1500 \mathrm{~nm}$ AND $25 \mathrm{~nm}$ RESPECTIVELY, $T=300 \mathrm{~K}$

\begin{tabular}{ccccc}
\hline \hline Thickness $\mathrm{ZnO}: \mathrm{Al}(\mathrm{nm})$ & $V_{O C}(\mathrm{~V})$ & $J_{S C}\left(\mathrm{~mA} / \mathrm{cm}^{2}\right)$ & $\mathrm{FF} \%$ & $\eta(\%)$ \\
\hline 5 & 1.47 & 23.62 & 75.15 & 26.16 \\
10 & 1.47 & 23.61 & 75.15 & 26.15 \\
15 & 1.47 & 23.60 & 75.15 & 26.15 \\
20 & 1.47 & 23.58 & 75.14 & 26.14 \\
30 & 1.47 & 23.55 & 75.14 & 26.12 \\
50 & 1.47 & 23.55 & 75.13 & 26.08 \\
100 & 1.47 & 23.47 & 75.12 & 25.99 \\
200 & 1.47 & 23.33 & 75.09 & 25.82 \\
\hline \hline
\end{tabular}

\section{Conclusion}

In this paper, the performance of the thin film -based solar cells has been studied. Different buffers such as $\mathrm{CdS}, \mathrm{ZnSe}, \mathrm{ZnS}, \mathrm{In} 2 \mathrm{~S} 3$, and CdSe have been used. The results have showed that $\mathrm{ZnSe}$ and $\mathrm{ZnS}$ as buffer layers have provided cell efficiency parameters approximately close to the cell that used $\mathrm{CdS}$ as a buffer layer. It has been concluded that $\mathrm{ZnSe}$ or $\mathrm{ZnS}$ could be used as an alternative material to $\mathrm{CdS}$.

Numerical simulation shows that the highest efficiency of $p-n$ heterojunction of $\mathrm{Mo} / \mathrm{ZnTe} / \mathrm{ZnSe} / \mathrm{ZnO}: \mathrm{Al}$ solar cell is equal to $25.34 \%$ (with $V_{O C}$ of $1.4615 \mathrm{~V}, J_{S C}$ of $23.30 \mathrm{~mA} / \mathrm{cm}^{2}$ and fill factor of $74.4 \%$ ). This efficiency can be achieved with an absorber ZnTe layer thickness equal to $1500 \mathrm{~nm}$, a buffer $\mathrm{ZnSe}$ layer thickness of $25 \mathrm{~nm}$, and a $\mathrm{ZnO}$ : Al window layer of a thickness of $50 \mathrm{~nm}$. From the simulation results, it is found out that the contribution of the space charge region in the photocurrent density is dominant compared to the ones of the neutral regions. These findings are very promising and provide helpful guidance for future thin and high performance of thin-film $\mathrm{Mo} / \mathrm{ZnTe} / \mathrm{ZnSe} / \mathrm{ZnO}: \mathrm{Al}$ solar cells.

\section{Acknowledgements}

We gratefully acknowledge Dr. Marc Burgelman, University of Gent, Belgium, for providing the SCAPS1D simulation software.

Furthermore, we are grateful to Ajman University for supporting this study. 


\section{References}

[1] Qasim, M., Velkin, V., Maximum Power Point Tracking Techniques for Micro-Grid Hybrid Wind and Solar Energy Systems - a Review, (2020) International Journal on Energy Conversion (IRECON), 8 (6), pp. 223-234. doi: https://doi.org/10.15866/irecon.v8i6.19502

[2] Dib, K., Chenni, R., A Combined MPPT Algorithm for Photovoltaic Systems Based Arduino Microcontroller, (2018) International Journal on Energy Conversion (IRECON), 6 (2), pp. 66-75.

doi: https://doi.org/10.15866/irecon.v6i2.15090

[3] Abadi, I., Musyafa, A., Baskoro, K., Fitriyanah, D., Design and Implementation of Mobile Active Two-Axis Solar Tracker with Reflector Based on Particle Swarm Fuzzy Controller, (2019) International Review on Modelling and Simulations (IREMOS), 12 (2), pp. 113-122. doi: https://doi.org/10.15866/iremos.v12i2.16739

[4] Khemmook, P., Khomfoi, S., Solid State Transformers Using Selective Harmonic Elimination Technique for Solar Farm Applications, (2020) International Review of Electrical Engineering (IREE), 15 (6), pp. 443-455. doi: https://doi.org/10.15866/iree.v15i6.17654

[5] Thang, V., A Stochastic Programming Approach for Energy Hubs Integrated with Renewable Energy Sources Based on Life Cycle Cost, (2020) International Journal on Energy Conversion (IRECON), 8 (3), pp. 90-101. doi: https://doi.org/10.15866/irecon.v8i3.18852

[6] Younis, R., Ibrahim, D., Aboul-Zahab, E., El'Gharably, A., Techno-Economic Investigation Using Several Metaheuristic Algorithms for Optimal Sizing of Stand-Alone Microgrid Incorporating Hybrid Renewable Energy Sources and Hybrid Energy Storage System, (2020) International Journal on Energy Conversion (IRECON), 8 (4), pp. 141-152. doi: https://doi.org/10.15866/irecon.v8i4.19137

[7] M. Upasani, S. Patil, Grid connected solar photovoltaic system with battery storage for energy management, in: 2018 2nd International Conference on Inventive Systems and Control (ICISC), IEEE, pp. 438-443, 2018.

[8] Zizoui, M., Tabbache, B., Zia, M., Benbouzid, M., Control of Isolated Photovoltaic-Battery-Ultracapacitor Microgrid for Remote Areas, (2020) International Journal on Energy Conversion (IRECON), 8 (2), pp. 38-44. doi: https://doi.org/10.15866/irecon.v8i2.18969

[9] Massaq, Z., Chbirik, G., Abounada, A., Brahmi, A., Ramzi, M., Control of Photovoltaic Water Pumping System Employing NonLinear Predictive Control and Fuzzy Logic Control, (2020) International Review on Modelling and Simulations (IREMOS), 13 (6), pp. 373-382. doi: https://doi.org/10.15866/iremos.v13i6.18615

[10] Arief, A., Nappu, M., Rachman, S., Photovoltaic Allocation with Tangent Vector Sensitivity, (2020) International Journal on Energy Conversion (IRECON), 8 (3), pp. 71-79. doi: https://doi.org/10.15866/irecon.v8i3.18419

[11] S. Madi, A. Kheldoun, Bond graph based modeling for parameter identification of photovoltaic module, Energy, 141, 1456-1465, 2017.

[12] I. Rimmaudo, A. Salavei, A. Romeo, Effects of activation treatment on the electrical properties of low temperature grown CdTe devices, Thin Solid Films, 535, 253-256, 2013.

[13] M.A. Green, K. Emery, W. Yoshihiro Hishikawa, EDD, Solar cell efficiency tables (Version 45). Prog Photovolt Res Appl, 23, 659676, 2007.

[14] S. Yang, S. Chen, E. Mosconi, Y. Fang, X. Xiao, C. Wang, Y. Zhou, Z. Yu, J. Zhao, Y. Gao, Stabilizing halide perovskite surfaces for solar cell operation with wide-bandgap lead oxysalts, Science, 365, 473-478, 2019.

[15] S.K. Das, S. Ganguli, H. Kabir, J.I. Khandaker, F. Ahmed, Performance of Natural Dyes in Dye-Sensitized Solar Cell as Photosensitizer, Transactions on Electrical and Electronic Materials, 21, 105-116, 2020

[16] O. Oklobia, G. Kartopu, S. JC Irvine, Properties of ArsenicDoped ZnTe Thin Films as a Back Contact for CdTe Solar Cells, Materials, 12(22), 3706, 2019.
[17] W. Lin, W. Wu, Z. Liu, K. Qiu, L. Cai, Z. Yao, B. Ai, Z. Liang, H. Shen, Chromium trioxide hole-selective heterocontacts for silicon solar cells, ACS applied materials \& interfaces, 10, 13645$13651,2018$.

[18] P. Qin, Q. He, G. Yang, X. Yu, L. Xiong, G. Fang, Metal ions diffusion at heterojunction chromium Oxide/CH3NH3PbI3 interface on the stability of perovskite solar cells, Surfaces and Interfaces, 10, 93-99, 2018.

[19] M. Ullah, R. Ali, G. Murtaza, Y. Chen, First principles investigation of $\mathrm{Be} 3 \mathrm{X} 2(\mathrm{X}=\mathrm{N}, \mathrm{P}, \mathrm{As})$ and their alloys for solar cell applications, Journal of Alloys and Compounds, 795, 385390, 2019.

[20] S. Rajpal, S. Kumar, Thermoluminescent properties of nanocrystalline $\mathrm{ZnTe}$ thin films: Structural and morphological studies, Physica B: Condensed Matter, 534, 145-149, 2018

[21] J.A. Luceño-Sánchez, A.M. Díez-Pascual, R. Peña Capilla, Materials for photovoltaics: State of art and recent developments, International Journal of Molecular Sciences, 20(4), 976, 2019.

[22] P. Tonui, S.O. Oseni, G. Sharma, Q. Yan, G.T. Mola, Perovskites photovoltaic solar cells: An overview of current status, Renewable and Sustainable Energy Reviews, 91(C), 1025-1044, 2018.

[23] J. Ramanujam, D.M. Bishop, T.K. Todorov, O. Gunawan, J. Rath, R. Nekovei, E. Artegiani, A. Romeo, Flexible CIGS, CdTe and aSi: $\mathrm{H}$ based thin film solar cells: A review, Progress in Materials Science, 110, 100619, 2020.

[24] S. Rajpal, S. Kumar, Thermoluminescent properties of nanocrystalline $\mathrm{ZnTe}$ thin films: Structural and morphological studies, Physica B: Condensed Matter, 534, 145-149, 2018.

[25] O. Skhouni, A. El Manouni, B. Mari, H. Ullah, Numerical study of the influence of $\mathrm{ZnTe}$ thickness on $\mathrm{CdS} / \mathrm{ZnTe}$ solar cell performance, The European Physical Journal Applied Physics, 74(2), 24602, 2016.

[26] I. Repins, M.A. Contreras, B. Egaas, C. DeHart, J. Scharf, C.L. Perkins, B. To, R. Noufi, 19. 9\%-efficient $\mathrm{ZnO} / \mathrm{CdS} / \mathrm{CuInGaSe} 2$ solar cell with $81.2 \%$ fill factor, Progress in Photovoltaics: Research and applications, 16, 235-239, 2008.

[27] J. Lindahl, U. Zimmermann, P. Szaniawski, T. Törndahl, A. Hultqvist, P. Salomé, C. Platzer-Björkman, M. Edoff, Inline $\mathrm{Cu}$ (In, Ga) Se \$ \{2\} \$ Co-evaporation for High-Efficiency Solar Cells and Modules, IEEE Journal of Photovoltaics, 3, 1100-1105, 2013.

[28] M. Powalla, P. Jackson, W. Witte, D. Hariskos, S. Paetel, C. Tschamber, W. Wischmann, High-efficiency cu (in, ga) se2 cells and modules, Solar Energy Materials and Solar Cells, 119, 51-58, 2013.

[29] A. Chirilă, S. Buecheler, F. Pianezzi, P. Bloesch, C. Gretener, A.R. Uhl, C. Fella, L. Kranz, J. Perrenoud, S. Seyrling, Highly efficient $\mathrm{Cu}$ (In, Ga) Se 2 solar cells grown on flexible polymer films, Nature materials, 10, 857-861, 2011.

[30] C. Platzer-Bjorkman, J. Kessler, L. Stolt, Atomic layer deposition of $\mathrm{Zn}(\mathrm{O}, \mathrm{S})$ buffer layers for high efficiency $\mathrm{Cu}$ (In, Ga) Se/sub 2/solar cells, in: Proceedings of the 3rd World Conference onPhotovoltaic Energy Conversion, 2003, IEEE, pp. 461-464, 2003.

[31] Y. Chiba, F. Meng, A. Yamada, M. Konagai, Study on phase transition of zn1-xmgxo thin films grown by mocvd process, in: 2006 IEEE 4th World Conference on Photovoltaic Energy Conference, IEEE, pp. 567-570, 2006.

[32] N. Naghavi, E. Chassaing, M. Bouttemy, G. Rocha, G. Renou, E. Leite, A. Etcheberry, D. Lincot, Electrodeposition of In2S3 buffer layer for $\mathrm{Cu}(\mathrm{In}, \mathrm{Ga}) \mathrm{Se} 2$ solar cells, Energy Procedia, 10, 155$160,2011$.

[33] F. Liu, J. Zhu, J. Wei, Y. Li, M. Lv, S. Yang, B. Zhang, J. Yao, S. Dai, Numerical simulation: toward the design of high-efficiency planar perovskite solar cells, Applied Physics Letters, 104, 253508, 2014.

[34] R. Benadli, B. Khiari, A. Sellami, Three-phase grid-connected photovoltaic system with maximum power point tracking technique based on voltage-oriented control and using sliding mode controller, in: IREC2015 The Sixth International Renewable Energy Congress, IEEE, pp. 1-6, 2015.

[35] Adam, K., Miyauchi, H., Optimization of a Photovoltaic Hybrid Energy Storage System Using Energy Storage Peak Shaving, (2019) International Review of Electrical Engineering (IREE), 14 
(1), pp. 8-18.

doi: https://doi.org/10.15866/iree.v14i1.16162

[36] El Malah, M., Ba-razzouk, A., Guisser, M., Abdelmounim, E., Madark, M., Bahri, H., Nonlinear Predictive Control for Maximum Power Point Tracking and Unity Power Factor of a Three Phase Grid Connected PV System, (2018) International Review of Automatic Control (IREACO), 11 (3), pp. 133-142. doi: https://doi.org/10.15866/ireaco.v11i3.14320

[37] Piarah, W., Djafar, Z., Hariyanto, H., Mustofa, M., A New Simulation of Photovoltaic and Thermoelectric Generator Hybrid System with a Beam Splitter Cold and Hot Mirror for Low Intensity, (2019) International Review of Mechanical Engineering (IREME), 13 (9), pp. 559-567. doi: https://doi.org/10.15866/ireme.v13i9.17884

[38] Omar, M., Mahmoud, M., Design and Simulation of DC/DC Boost Converter with Maximum Power Point Tracking for Grid Connected PV Inverter Considering the Nonlinearity of the PV Generator, (2019) International Journal on Energy Conversion (IRECON), 7 (6), pp. 241-252.

doi: https://doi.org/10.15866/irecon.v7i6.18250

[39] M. Burgelman, P. Nollet, S. Degrave, Modelling polycrystalline semiconductor solar cells, Thin solid films, 361, 527-532, 2000.

[40] K. Decock, S. Khelifi, M. Burgelman, Modelling multivalent defects in thin film solar cells, Thin Solid Films, 519, 7481-7484, 2011.

[41] J. Verschraegen, M. Burgelman, Numerical modeling of intraband tunneling for heterojunction solar cells in SCAPS, Thin Solid Films, 515, 6276-6279, 2007.

[42] M. Burgelman, J. Verschraegen, S. Degrave, P. Nollet, Modeling thin-film PV devices, Progress in Photovoltaics: Research and Applications, 12,143-153, 2004.

[43] H. Movla, Optimization of the CIGS based thin film solar cells: Numerical simulation and analysis, Optik, 125, 67-70, 2014.

[44] N. Amin, A. Yamada, M. Konagai, Effect of ZnTe and CdZnTe Alloys at the Back Contact of 1- $\mu$ m-Thick CdTe Thin Film Solar Cells, Japanese Journal of Applied Physics, 41, 2834, 2002.

[45] N. Paudel, K. Wieland, A. Compaan, Ultrathin CdS/CdTe solar cells by sputtering, Solar Energy Materials and Solar Cells, 105, 109-112, 2012.

[46] P. Singh, N.M. Ravindra, Temperature dependence of solar cell performance-an analysis, Solar energy materials and solar cells, 101, 36-45, 2012.

[47] J.P. Becque, D. Halliday, Modelling an optimised thin film solar cell, European Journal of Physics, 40, 025501, 2019.

[48] Y. Inoue, M. Hála, A. Steigert, R. Klenk, S. Siebentritt, Optimization of buffer layer/i-layer band alignment, in: 2015 IEEE 42nd Photovoltaic Specialist Conference (PVSC), IEEE, pp. $1-5,2015$.

[49] N. Khoshsirat, N.A.M. Yunus, Numerical simulation of CIGS thin film solar cells using SCAPS-1D, in: 2013 IEEE Conference on Sustainable Utilization and Development in Engineering and Technology (CSUDET), IEEE, pp. 63-67, 2013.

[50] N. Kaur, M. Singh, D. Pathak, T. Wagner, J. Nunzi, Organic materials for photovoltaic applications: Review and mechanism, Synthetic Metals, 190, 20-26, 2014.

\section{Authors' information}

${ }^{1}$ Department of Mathematics and Sciences, Ajman University, Ajman, United Arab Emirates.

${ }^{2}$ Nonlinear Dynamics Research Center (NDRC), Ajman University, Ajman, United Arab Emirates.

${ }^{3}$ Department of Chemistry, An-Najah National University, Nablus, Palestine.

${ }^{4}$ School of Physics, Universiti Sains Malaysia, 11800, USM Penang, Malaysia.

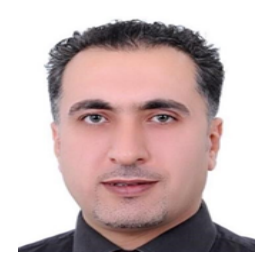

Samer H. Zyoud was born in Palestine, received the B.Sc. degree in physics from University of Mosul, Al- Mosul, Iraq, in 2001, the M.Sc. degree in physics from University of Baghdad, Baghdad, Iraq, in 2003, at present, he has been working as senior lecturer at Ajman University, Ajman, United Arab Emirates and PhD Student at University Sains Malaysia, Penang, Malaysia. Research area: Nanostructures Thin Film - based (Solar cell, Photocatalyst, Sensor) and semiconductor laser with application.

E-mail: s.zyoud@ajman.ac.ae

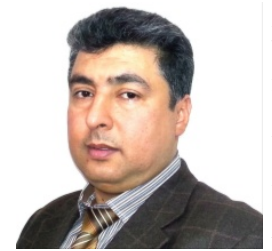

Ahed H. Zyoud (Corresponding Author) was born at Seilat Al-Harthiya/Jenin in 1973, received the B.Sc. at the Yarmouk University, Jordan in 1996, M.Sc. at An-Najah National University, Palestine in 2000, and the Ph.D. at An-Najah National University, Palestine in 2009. Zyoud is a professor at An-Najah national university, Chemistry department. His research activity is focused on material and nanotechnology, preparation, and characterization. Applications of the prepared nanomaterials in the fields of thin-film photovoltaic application in addition photodegradation of water organic contaminants.

E-mail: ahedzyoud@najah.edu

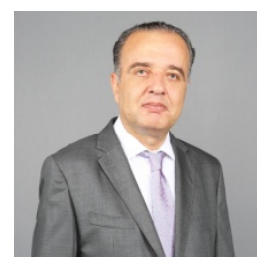

Atef Abdelkader was born in Palestine and got his B.Sc in physics from Garyounes University, Libya 1992 and MSc and PhD from The Queen's University, U.K 1995 and 1998. At present, he is the head of maths and science department, Ajman University, UAE. He has an interest in a number of research areas like Material Science, Nanostructures thin film, Semiconductor Laser, and Optical System Technology - Any area where science is applied. E-mail: a.abdelkader@ajman.ac.ae

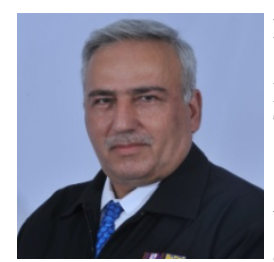

Naser M. Ahmed received his B.Sc degree 1984 in Physics from Almustansiriah University, M.Sc. laser technology 1988 from University of Technology, Iraq, and $\mathrm{PhD}$ from Universiti Sains, Malaysia, in 2006. Recently, working as a Senior lecturer at the School of Physics, Universiti Sains Malaysia. He is the author/coauthor of more than 310 research papers published in international journals, two patents, and is the author of 6 books. His current research interests in Laser design, laser ablation, LED, Nanorods, $\mathrm{pH}$ sensor, quantum dots, and photodetector. E-mail: naser@usm.my 